\title{
Self-Determination, Resources and Borders: Introduction to the Special Issue
}

\section{JAMES SUMMERS*}

This special edition developed from the "Conference on $21^{\text {st }}$ Century Borders" held at Lancaster University on 13 June 2014. This conference took place in the context of the Russian invasion and annexation of Crimea earlier in March, but sought to address tensions over borders more widely. A key assumption in the UN system is that changes in political and economic relations can take place between states within established borders. However, not only in Russia's asserted 'near abroad', but also in Asia, a shifting balance of power has stoked territorial tensions. In Asia many of these have focussed competing claims over islands and marine resources amongst countries bordering the South and East China seas. This special edition will look at disputes over borders and resources, not only from the perspective of self-determination but also from broader principles for the settlement of territorial claims.

Borders are an inevitable part of self-determination. The subject of the right, the people, by necessity, is distinguished from other peoples by the boundaries used to define it, both internally and externally. ${ }^{1}$ In addition, the state, which is territorially-defined, forms the principal object of the right. It is either a mechanism for its realisation, if the right is aimed to be realised 'internally' within a state, or a model for a new political entity, in the case of secession.

Nonetheless, while borders are an inherent element in self-determination, their relationship with it has not been rigid and evolved over time. After the right gained international currency in the First World War, plebiscites were used in limited circumstances to change established borders in accordance with the wishes of the people. ${ }^{2}$ The UN Charter developed clear protection for a territorially-defined inter-state system with its unambiguous formulation of the principle of the territorial integrity of states in Article 2(4). Nonetheless, there little examination in the drafting of the relationship between this principle and that of selfdetermination in articles 1 and 55, aside from condemnation of the latter as a basis for intervention. $^{3}$

The emergence of self-determination as a legal right in the decolonisation process, though, was closely connected with territorial integrity. The colonial units entitled to selfdetermination, and their exercise of that right, were territorially defined. Colonial territories were asserted to have a separate political status from the states administering them. ${ }^{4}$ Their territorial integrity was upheld in Principle 6 of the Declaration on the Granting on Colonial Independence, GA Res. 1514(XV) 1960. This protected their unity against actions by administering powers to dismember them (e.g. the separation of Walvis Bay from Namibia) ${ }^{5}$ and after independence against secessionist movements (e.g. Katanga or Biafra).

\footnotetext{
* Lecturer in Law, University of Lancaster. I would like to thank the contributors to this special edition and the Conference on $21^{\text {st }}$ Century Borders, as well as Wang Linzhu, Amanda Cahill-Ripley, Sophia Kopela, Steven Wheatley and James Sweeney.

${ }^{1}$ F. Barth, 'Introduction' in F. Barth (ed.), Ethnic Groups and Boundaries: The Social Organization of Cultural Difference (Scandinavian University Books, Bergen, 1969) pp. 9-35.

2 See S. Wambaugh, Plebiscites Since the World War with a Collection of Official Documents (Carnegie Endowment for International Peace, Washington, 1933)

${ }^{3}$ See comments of the Rapporteur, Committee. I/1, 15 May 1945, p. 12.

${ }^{4}$ Principle 5(6), Declaration on Principle of Friendly Relations, GA Res. 2626 (XXV) 1970.

${ }^{5}$ GA Res. 32/9D (1977); SC Res. 432 (1978).
} 
However, in the early stages of decolonisation, the partition of a colonial territory was not that unusual ${ }^{6}$ and still continued in some cases after $1960 .^{7}$ Moreover, the principle of territorial integrity in resolution 1514 (XV), was directed towards the unity of a "country", a term much more open to interpretation than "non-self-governing territory" or "state". The ICJ's Western Sahara Advisory Opinion (1975) one of the landmark decisions on the colonial right also recognised its relationship with territorial sovereignty. However, this relationship was not explored further and the Court may have left open the possibility of the partition of the territory. 8

This relationship between self-determination and principle of territorial integrity was also clearly intended to limit the use of the right in secession. While there was support for extending the right beyond the narrow UN concept of colonialism to the more ambiguous context of people under alien subjugation - a context affirmed by the ICJ in the Kosovo Opinion (2010) $)^{9}$ - there was no intent to encourage independence movements within states.

However, the limits imposed by territorial integrity on secession depended on two factors. The first was whether the principle was framed in terms that amounted to a prohibition. Provisions on territorial integrity, though, are more nuanced, referring to compatibility with the Charter ${ }^{10}$ or compatibility with relevant norms, ${ }^{11}$ rather than an explicit prohibition. The most flexible position is in the Declaration on Friendly Relations which does not authorise or encourage acts against the territorial integrity of a state, where that state allows nondiscriminatory enjoyment of self-determination by its people. This creates an explicit conditionality around territorial integrity, albeit in the context of strengthening it by rooting the principle in representative government.

The second was whether such a prohibition, in any case, applied to secessionist movements as non-state actors, rather than to states which might be legally constrained from recognising them. This was the position taken by the ICJ in Kosovo, ${ }^{12}$ though as Simone van den Driest notes in her article, this was based on a narrow selection of instruments on with territorial integrity that did not actually address its relationship with self-determination. In her article she argues for a wider more nuanced approach. The Court consciously avoided the question of whether territorial integrity affected non-state actors as holders of a right to selfdetermination, distinguishing itself from the Canadian Supreme Court in Re Secession of Quebec (1998). The Canadian Court had indeed found that the right was expected to be exercised "within the framework of existing sovereign states and consistently with the maintenance of the territorial integrity of those states". ${ }^{13}$ However, as Alexander Orakhelashvili explores in his article, this narrow focus allowed two competing frameworks to emerge: independence unilaterally declared by Kosovo authorities and the regime

\footnotetext{
${ }^{6}$ See, e.g., Palestine (GA Res. 181 (III) (1947)). Partition was contemplated in the UN Report on Eritrea. Report of the United Nations Commission for Eritrea, 5 GAOR (1950) Supplement No. 8 (A/1285) paras. 161 and 176. See also J. S. Coleman, 'Togoland', 509 International Conciliation (1956) pp. 78-79 on British Togoland and GA Res. 1352 (XIV) (1959); GA Res. 1471 (XIV) (1959); GA Res. 1608 (XV) (1960) on the British Cameroons.

${ }^{7}$ See Rwanda and Burundi (GA Res. 1746 (XVI) (1961)); Kiribati and Tuvalu (GA Res. 3288 (XXIX) (1974); GA Res. 3426 (XXX) (1975); Micronesia (see A. J. Armstrong and H. L. Hills, 'The Negotiations for the Future Political Status of Micronesia (1980-1984)’, 78 American Journal of International Law (1984) pp. 484-497).

${ }^{8}$ Western Sahara, 16 October 1975, ICJ, Advisory Opinion, I.C.J. Reports 1975, p. 68, para. 162 and p. 37, para. 72.

9 Accordance with International Law of the Unilateral Declaration of Independence in Respect of Kosovo (Advisory Opinion), 22 July 2010, ICJ, Advisory Opinion, I.C.J. Reports 2010, p. 436, para. 79.

${ }^{10}$ Principle 6, Declaration on the Granting of Independence to Colonial Countries and Peoples, GA Res. 1514 (XV) 1960.

${ }^{11}$ Principle VIII, Helsinki Final Act 1975.

${ }^{12}$ Kosovo (Advisory Opinion), supra note 9, p. 437, para. 80.

${ }^{13}$ Reference re: Secession of Quebec, [1998] D.L.R $4^{\text {th }}$ Series, p. 436, para. 122.
} 
established by the Security Council which still forms a basis for multilateral involvement in the territory.

A second territorial principle relating to self-determination is uti possidetis, which emerged in Latin America and upheld the borders of a colonial territory at the time of its independence. Uti possidetis differs from the territorial integrity of states in that the latter principle applies to a state's borders after its independence, while the former defines them when statehood is being established. Nonetheless, in decolonisation this difference was less significant. Territorial integrity in Principle 6 of the Declaration on Colonial Independence was used both to maintain the borders of a colony prior to independence and a state after that. The ICJ in Burkina Faso/Mali (1986) considered that, despite the ethnic diversity in the continent, self-determination in the African context was exercised consistently with the principle. ${ }^{14}$ The Badinter Commission, which advised on EU (EC) recognition policy in the break-up of Yugoslavia, developed on the Court's description of it as a general principle to apply it to that states' dissolution. ${ }^{15}$ This general extension has remained controversial and Arman Sarvarian in his article argues a consensual basis for the application of the principle.

A third principle which has emerged in relation to self-determination and borders was the inviolability of frontiers, proclaimed in Principle III of the Helsinki Final Act. This principle was intended to add another layer of protection to states' borders, and was promoted in the Final Act by the Soviet Union to secure the boundaries it imposed in Europe in the Second World War. However, other states in the drafting, notably Germany and Ireland, did not view inviolability as immutability. ${ }^{16}$ Russia after its invasion of Crimea has argued that selfdetermination can take place over existing state borders, with language very similar to that of Serbia in the early 1990s. ${ }^{17}$ Russian President Vladimir Putin, for example, described the Russian nation as "one of the biggest, if not the biggest ethnic group to be divided by borders." ${ }^{18}$ However, it is notable that exceptions to inviolability of frontiers were based on the consent of states. Indeed, German reunification in 1990, though presented as an act of self-determination, could also simply be seen as the consent-based absorption of one state by another. ${ }^{19}$ Moreover, integral elements of consent in this process were guarantees for the borders of neighbouring states. ${ }^{20}$

A right to resources relates to self-determination primarily through its economic aspect, also known as the right to permanent sovereignty. Many of these resources lie on the seabed or around rocks and uninhabited islets leaving Judge Dillard's dictum: "It is for the people to determine the destiny of the territory not the territory the destiny of the people" ${ }^{21}$ - quoted by some contributors - superficially empty. Nonetheless, many states in their reports on the implementing economic aspects of self-determination under Article 1 of the Human Rights Covenants have focused on marine resources, such as exclusive economic zones. ${ }^{22}$ Claims over marine delimitation, though, have centred on principles such as occupation, as

\footnotetext{
${ }^{14}$ Burkina Faso/Mali Frontier Dispute, 22 December 1986, ICJ, Judgment, I.C.J. Reports 1986, p. 567, para. 25.

${ }^{15}$ Opinion No. 3, 31 I.L.M. (1992) p. 1500.

${ }^{16}$ Federal Republic of Germany, (CSCE/II/A/3) p. 4; Ireland, (CSCE/I/PV.6) p. 86.

17 See, e.g., Letter dated 11 June 1993 from the Chargé d' affairs a.i. of the Permanent Mission of Yugoslavia to the United Nations Addressed to the Secretary-General, UN Doc. A/48/207 - S/25936, p. 2.

${ }^{18}$ Address by the President of the Russian Federation, 18 March 2014, <eng.kremlin.ru/news/6889>, visited on 24 July 2015.

${ }^{19}$ See J. Summers, Peoples and International Law (2nd ed, Martinus Nijhoff, Leiden, 2014) pp. 471-472.

${ }^{20}$ See Article 1, Treaty on the Final Settlement with Respect to Germany, 12 September 1990, 29 I.L.M. (1990) p. 1188.

${ }^{21}$ Judge Dillard, Separate Opinion, Western Sahara, 16 October 1975, ICJ, Advisory Opinion, I.C.J. Reports 1975, p. 122.

22 See, e.g., Togo, Initial Report 2010, E/C.12/TGO/1, para. 246; Spain, Fifth Periodic Report 2009, E/C.12/ESP/5, paras. 31 and 34; Mauritius, Fourth Periodic Report 2008, E/C.12/MUS/4, para. 162;
} 
highlighted by Joshua Castellino and Elvira Dominguez Redondo in their study of the KoreaJapan dispute over the Dokdo/Takishima islets. A particular problem in these disputes has been the unwillingness of the parties to submit to international adjudication. However, even in such cases there may be questions of how principles should approached to achieve a fair delimitation, and indeed whether fairness might precede them - a question explored in Duncan French's article.

Economic self-determination and a peoples' right to resources has also become increasingly interconnected with international environmental law. A people's right to freely pursue their economic and social development provided for in Article 1 of the Human Rights Covenants can be seen as one of sustainable development. ${ }^{23}$ Likewise, the process of decision-making in the right can encompass environmental principles and procedures, such as duties of notification, consultation and the conduct of environmental impact assessments. ${ }^{24}$ David Ong's article examines these environmental principles as a mechanism for defusing tensions in territorial disputes in the South China Sea. Altogether these articles raise new questions about the role and potential of territorial principles and their relationship with resources and self-determination.

\section{Simone F. van den Driest}

Simone F. van den Driest' article examines the scope of the principle of territorial integrity and its implications for unilateral secession in light of Crimea and the Kosovo Advisory Opinion. She questions the widely-accepted position, also adopted by the ICJ in Kosovo, of international law's neutrality on secession. Instead, drawing from practice she considers whether there is justification for a more inclusive interpretation of territorial integrity that encompasses non-state actors. Her argument is that international law takes a more nuanced approach towards secession. Behind its apparent neutrality, the law, in fact, does erect legal barriers which against a right of self-determination used by non-state actors. Indeed, aside from its exercise within states, avenues for this right are largely closed with the weak status of remedial secession in international law.

\section{Alexander Orakhelashvili}

Secessionist regions that do manage to assert de facto control, nonetheless, may remain in legal limbo. Alexander Orakhelashvili's article addresses the lingering contradiction between the unilateral declaration of independence by Kosovo authorities, not found by the ICJ to be contrary to international law in 2010 and the Court's recognition of a continuing multilateral framework. The contradictions in this decision still divide the international community. The article charts the difficult characterisation of Kosovo before the European Court of Human Rights, in international agreements and in the role and authority of international organisations on its territory.

\footnotetext{
${ }^{23}$ See, e.g., Peru, Third Periodic Report 1995, CCPR/C/83/Add.1, para. 11; Columbia, Fourth Periodic Report 1996, CCPR/C/103/Add.3, para. 16; Estonia, Report 2002, CCPR/C/EST/2002/2, para. 12;

${ }^{24}$ The Social and Economic Rights Action Center and the Center for Economic and Social Rights v. Nigeria ('Ogoniland Case'), ACHPR, Communication No. 155/96 (2001), para. 53; Centre for Minority Rights Development (Kenya) and Minority Rights Group International on behalf of Endorois Welfare Council v. Kenya ('Endorois Case'), ACHPR, Communication No. 276/2003 (2009), para. 266. See also Poma Poma v. Peru, HRC, Communication No. 1457/2006 (2009) paras. 2.3, 2.6-2.7, 4.2 and 7.7.
} 


\section{Arman Sarvarian}

Arman Sarvarian's article is a reappraisal of the position of uti possidetis in international law. In a careful study of practice, he challenges how far the principle has established itself beyond Spanish America. Surveying practice in this area, he makes a case for it to be considered at best a limited regional rather than general custom. In his assessment, though the principle has been widely applied, it has been more on a consensual basis. In his view, instead of a bastion of state succession, as is commonly presented, uti possidetis is not presumptive, but one of a number of principles available in territorial dispute settlement.

\section{Duncan French}

Duncan French's article, "You will Always have the Poor”, a title taken from a passage in the Bible, is a reflection on the fundamental tensions underpinning the law on territorial delimitation. He asks whether fairness in the allocation of resources, especially in relation to the disadvantaged "poor" is achieved through perceptions of justice or the negotiation of normative rules. This interrelationship is explored using examples if loss of territory through sea-level rise and the ICJ's 2014 decision in the Peru v. Chile case. It examines the practice of the court in relation to fairness and delimitation and its vacillating approach to the principle of equity. Professor French argues that the goal of justice should not be at the expense of normative rules, which provide certainty and stability essential for the legitimacy of judicial territorial delimitation.

\section{Joshua Castellino and Elvira Redondo Domínguez}

While many territorial disputes have implications for the population of a territory, some of the most fiercely contested conflicts in Asia involve uninhabited territories. Joshua Castellino and Elvira Redondo Domínguez's addresses the dispute between Korea and Japan over the Dokdo/Takeshima islets. The article examines the historical context for the two country's claims, their legal basis and relative strength, as well as the prospects for dispute resolution. In their assessment, Korea has the strongest claim to title, but Japan may have established usus rights for its fishermen.

\section{David Ong}

While international law is inhibited in the resolution of territorial disputes in the South China Sea by a lack of compulsory dispute settlement procedures amongst states for such disputes, David Ong's article alternative legal mechanisms to defuse potential conflicts. He identifies three types of resource-related activities that could become flashpoints between countries in the region: land reclamation, concessions for off-shore hydrocarbon development and fishing activities. While not resolving the underlying territorial disputes, he argues that these points of tension could be alleviated by provisions in international environmental law. He identifies first obligations of notification and consultation which could apply to activities that affect the rights of other states. Second, there are duties to conduct environmental impact assessments and information-sharing for activities with an impact of freedom of navigation and the environment. Lastly, with receipt of this information, states may be required to engage in meaningful negotiations over their respective rights and obligations. 
